\title{
Perspectives and Recommendations for Laparoscopic Surgery in the COVID-19 Era
}

\author{
Andrés V Ayala ${ }^{1}$, Sofía A Zárate ${ }^{2}$, Andrés E Zabala ${ }^{3}$, Luis Pacheco ${ }^{4}$, Fernando I Narváez ${ }^{5}$, María L Alvear ${ }^{6}$, José R Negrete ${ }^{7}$
}

\begin{abstract}
A new human coronavirus called SARS-CoV-2 is currently causing a pandemic of the coronavirus disease 2019 (COVID-19). Healthcare institutions including surgical centers and their workers are in risk of contagion due to high exposure to SARS-CoV-2. The objective of the present manuscript is to review the available literature and elucidate the key points for maintaining safety in laparoscopic surgery during the pandemic. Currently, any patient who requires surgery and in whom the diagnosis of COVID-19 has not been ruled out should be treated as a positive patient and the correspondent safety measures should be taken. Surgical plume is a bioproduct that places healthcare workers who are exposed to it in a potential risk of acquiring different health conditions. There is no clear evidence to affirm that the exposure to surgical plume and pneumoperitoneum can cause COVID-19; nevertheless, as we do not know yet the real risk of transmission and infectivity of particles found in surgical smoke, it is recommended to take measures for a controlled evacuation of pneumoperitoneum and the use of a simple filtration system during laparoscopic surgery. We must understand that as our entire life changed with this pandemic, laparoscopic surgery should also change in particular aspects to give our patients the best treatment under the safest conditions as possible.
\end{abstract}

Keywords: COVID-19, Laparoscopy, SARS-CoV-2, Surgery.

\section{Resumen}

Un nuevo coronavirus humano llamado SARS-CoV-2 actualmente se encuentra ocasionando la pandemia de enfermedad de coronavirus 2019 (COVID-19). Las instituciones de salud, incluyendo los centros quirúrgicos y su personal, se encuentran en riesgo debido a la alta exposición al SARS-CoV-2. El objetivo de este manuscrito es revisar la literatura disponible y dilucidar los puntos claves requeridos para mantener la seguridad de la cirugía laparoscópica durante esta pandemia. En la actualidad cualquier paciente que requiera una intervención quirúrgica, en el que no se haya descartado COVID-19, debe ser tratado como positivo y por ende se deben tomar todas las medidas de protección pertinentes. El humo quirúrgico es un bioproducto que puede exponer al personal de salud a un potencial riesgo de adquirir diferentes patologías. No existe evidencia contundente para afirmar que la exposición al humo quirúrgico o al neumoperitoneo pueda causar COVID-19, sin embargo, en la actualidad no conocemos el riesgo real de transmission e infectividad de las partículas que se encuentran en el humo quirúrgico, es recomenable tomar medidas para conseguir una evacuación controlada del neumoperitoneo junto con el uso de un sistema de filtración simple durante la cirugía laparoscópica. Debemos entender que así como esta pandemia ha cambiado nuestra vida en general, la cirugía laparoscópica también debe cambiar en ciertos aspectos particulares para ofrecer a nuestros pacientes el mejor tratamiento bajo las condiciones más seguras posibles.

Palabras clave: COVID-19, Laparoscopía, SARS-CoV-2, Cirugía.

Panamerican Journal of Trauma, Critical Care \& Emergency Surgery (2020): 10.5005/jp-journals-10030-1279

\section{INTRODUCTION}

A novel human coronavirus, severe acute respiratory syndrome coronavirus 2 (SARS-CoV-2), emerged in Wuhan, China, at the end of 2019 leading to the current pandemic. ${ }^{1}$ It is an RNA virus whose size is 0.12 microns $(\mu \mathrm{m})$. It can be found in the nasopharynx, the upper and lower respiratory tract, and in the entire gastrointestinal tract, from the mouth to the anus. It is suspected that given the multiple locations that it can be found it has multiple transmission pathways. $^{2-5}$ Vertical transmission from mother to child has not been demonstrated. The RNA of SARS-CoV-2 has not been found in samples from the umbilical cord blood, vaginal discharge, or breast milk. ${ }^{6-8}$

The outbreak has extended rapidly throughout the world and it constitutes an international public health emergency. It also places the medical community and health workers who perform procedures at high risk due of exposure to the virus. Theoretically, the virus is still viable in aerosols for at least 3 hours and remains transmissible. ${ }^{9,10}$ As of June 6, 2020, the infection extended to 199 countries, with 6,663,304 confirmed cases and 392,802 deaths. In Ecuador, 42,106 cases and 3,592 deaths were reported. ${ }^{11}$

\footnotetext{
1Department of Surgery, Hospital del Instituto Ecuatoriano de Seguridad Social-Quito Sur, Quito, Ecuador; Department of Surgery, Hospital Vozandes Quito, Quito, Ecuador; Universidad Internacional del Ecuador, Quito, Ecuador

${ }^{2}$ Department of Surgery, Hospital Metropolitano de Quito, Quito, Ecuador

${ }^{3}$ Pontifica Universidad Católica del Ecuador, Quito, Ecuador

${ }^{4}$ Department of Surgery, Centro Médico Oncológico, Quito, Ecuador; Department of Surgery, Hospital Vozandes Quito, Quito, Ecuador

${ }^{5}$ Department of Internal Medicine, Hospital Metropolitano, Quito, Ecuador

${ }^{6}$ Hospital Vozandes Quito, Quito, Ecuador

${ }^{7}$ Department of Surgery, Hospital Vozandes Quito, Quito, Ecuador; Universidad Internacional del Ecuador, Quito, Ecuador

Corresponding Author: Andrés V Ayala, Department of Surgery, Hospital del Instituto Ecuatoriano de Seguridad Social-Quito Sur, Quito, Ecuador; Department of Surgery, Hospital Vozandes Quito, Quito, Ecuador; Universidad Internacional del Ecuador, Quito, Ecuador, Phone: (+593-2) 3980 100, Ext. 1060, e-mail: andres_pojkar@hotmail. com
} 
Previous studies of SARS-CoV-1 have demonstrated that endotracheal tube placement was highly associated with the transmission of infection to healthcare workers who perform the procedure. Additionally, other procedures such as tracheostomy, noninvasive ventilation, and mask bag ventilation performed before the endotracheal tube placement were associated with a high risk of infection. ${ }^{12}$

Considering the risks for the healthcare personnel in the operating room to contract the virus, most of the surgical services for elective procedures have been discontinued. This practice brings into question how and when surgeons should perform surgical procedures that are urgent or time-limited. This review will elucidate key points for safety in laparoscopic surgery in the midst of the SARS-CoV-2 pandemic.

\section{Preoperative Assessment}

The goal of preoperative assessment is to ensure the safety of the patients and the providers. The transmission of SARS-CoV-2 is primarily by droplets and/or contact with infected individuals that may or may not have symptoms. ${ }^{13-15}$ The disease is highly contagious. To date, there is not enough data to truly understand the exact reproductive number (R0). Some studies have estimated a mean R0 between 2.2 and 3.58. This means that each patient will propagate the infection to other 2-4 people. ${ }^{16,17}$ The incubation period of the virus can be as long as 14 days with a mean duration of 5.2 days. An asymptomatic carrier can have an incubation period up to 19 days and the majority of patients experience one or more symptoms at 12.5 days after initial contact with SARS-CoV-2. ${ }^{16,18,19}$

Patients with SARS-CoV-2 run the spectrum from asymptomatic carriers to a severe form of the disease leading to multisystem organ failure. When infected with SARS-CoV-2, it is referred to as COVID-19. Most patients present with fever, dry cough, myalgia, fatigue, anosmia, hyposmia, dysgeusia, and dyspnea. Less common symptoms include abdominal pain, dizziness, productive cough, pleuritic pain, and $10 \%$ of patients can present with nausea and diarrhea. ${ }^{3,16-21}$ At the beginning of the disease, the white blood count may be normal. Common laboratory findings in patients with COVID-19 include leukopenia and lymphopenia. It is also frequent to find elevated levels of ferritin, C-reactive protein (CRP), lactic dehydrogenase (LDH), creatine kinase (CK), aspartate aminotransferase (AST), alanine aminotransferase (ALT), and almost $30 \%$ of patients show an elevation of D-dimer. ${ }^{19,20,22}$

Computed tomography (CT) in patients with COVID-19 has characteristic image patterns related with different clinical types of the disease (mild, moderate, severe, and critical). ${ }^{22}$ The diagnosis of
How to cite this article: Ayala $A V$, Zárate $S A$, Zabala $A E$, et al. Perspectives and Recommendations for Laparoscopic Surgery in the COVID-19 Era. Panam J Trauma Crit Care Emerg Surg 2020;9(2): 126-132.

\section{Source of support: Nil}

Conflict of interest: None

COVID-19 is currently based on quantitative real-time polymerase chain reaction (RT-PCR). The universally recommended sample must be collected by the nasopharyngeal swab, which has a positive predictive value (PPV) that varies from 47 to $96 \%$ and a sensitivity of $89 \%$. Bronchoalveolar lavage has a sensitivity of $93 \% .{ }^{22,23}$ The sampling technique for a nasopharyngeal swab is difficult to perform accurately and this may increase the false-negative rate. This may account for the observation that the sensitivity of RT-PCR has been suggested in some series to be lower than the sensitivity of the thoracic CT scan. ${ }^{24,25}$

The antibody detection tests for immunoglobulin M (IgM) and immunoglobulin $\mathrm{G}$ (lgG) using immunochromatography are known as rapid tests and their sensitivity can be affected by various factors such as the disease progression time, the viral load of the patient, and the type of kit used, among others. Currently, we do not know with certainty the time required to develop antibodies nor the exact cutoff to consider a patient positive because of the novelty of the disease. Considering all of these factors, it has been estimated that the sensitivity for rapid tests varies from 34 to $80 \% .{ }^{26}$ In a patient with a rapid test negative result but a clinical course that would suggest COVID-19, a RT-PCRq should be performed as well. ${ }^{27}$

\section{Emergency Surgery}

If a patient presents with a potentially life-threatening condition that requires immediate surgical treatment and the situation does not allow time for the RT-PCR result, they should be considered a SARS-CoV-2 carrier. Between 18\% and 50.5\% of COVID-19 patients are asymptomatic carriers and can potentially transmit the disease. These patients should be treated using all the preventive measures and personal protective equipment the same as confirmed patients (Flowchart 1). 22,28,31 Safety measures should be taken during the preoperative workup, the surgical procedure, and in the postoperative period. In a suspected or confirmed case, additional caution is needed to guarantee contact and droplets isolation, which include the $\mathrm{N} 95$ respirator approved by the National Institute for Occupational Safety and Health (NIOSH), goggles, face shield, gown, double pair of gloves, and protective shoe covers. ${ }^{22,29-32}$

Flowchart 1: Assessment flow diagram for emergency surgery in symptomatic or asymptomatic patient

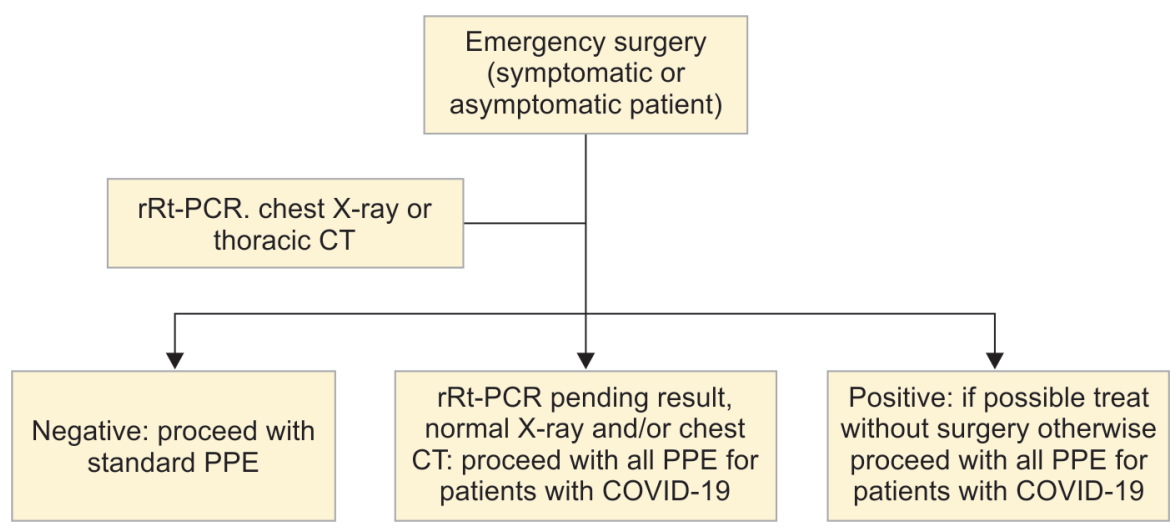




\section{Elective Surgery}

Every patient who needs an elective surgery should have a negative result from a RT-PCR test performed 48 hours prior to surgery and a complete preoperative evaluation. If the result of RT-PCR is positive, it is recommended to delay surgery, treat COVID-19 according to its severity, and repeat the RT-PCR 10-14 days after the first positive result. Surgery is considered safe when the RT-PCR result has turned negative. In cases in which the surgery cannot be delayed, the patient should be handled the same as emergency procedures (Flowchart 2). ${ }^{33,34}$

\section{Surgical Perspective in Patients with COVID-19}

Stahel stratified elective surgical procedures according to their urgency. This urgency should be analyzed on a case-by-case basis. This strategy will enable the surgeons to identify the optimal timing to perform each intervention during the pandemic (Table 1). ${ }^{35}$

In a retrospective study in Wuhan, which included 34 asymptomatic carriers who underwent elective surgery, none of them presented with COVID-19 symptoms at the time of surgery. They developed symptoms around the 5 th day of admission. All the patients developed pneumonia, $44 \%$ required the intensive care unit (ICU) and $20 \%$ died. Surgeries with a mean operative time of 200 minutes had a higher complication rate compared with those whose mean operative time was 70 minutes. ${ }^{36}$ Care must be taken to avoid viral exposure related to aerolization during surgery for those who are asymptomatic if tests are not available, which can result from assisted ventilation. ${ }^{1}$

\section{Surgical Plume as a Risk Factor for Healthcare Workers}

Surgical plume is a bi-product resulting from the use of electrosurgical devices and can lead to a theoretical biological risk in health care. It can have up to 150 products, which include toxic gases, nitriles, live and death cell material, bacteria, and active virus. ${ }^{37-40}$ Ball described that the incidence of respiratory disease such as asthma and sinusitis can be twice as common in full-time surgical healthcare workers compared to the general population. This finding was attributed to surgical plume inhalation. ${ }^{41}$

Flowchart 2: Assessment flow diagram for elective surgery patients

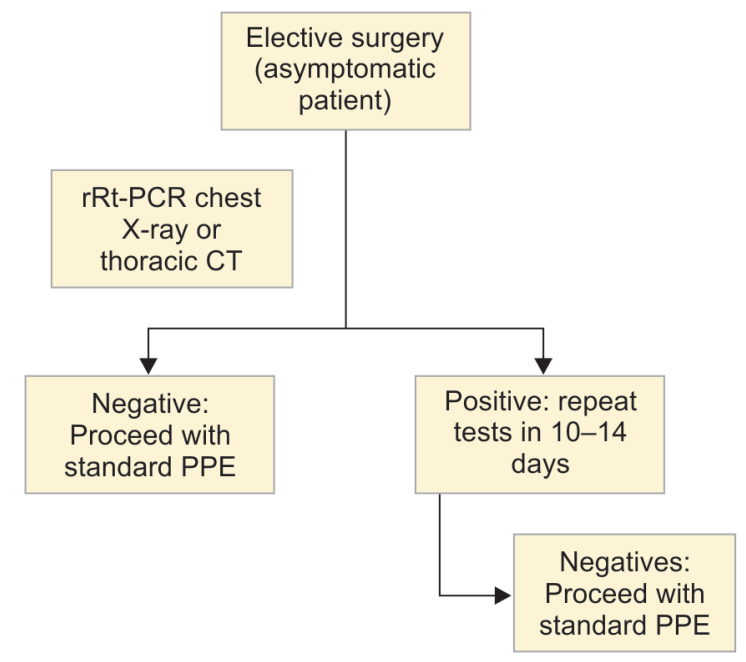

The concentration of particles in surgical plume after 10 minutes of using electrosurgical devices is higher in laparoscopic vs open surgery. ${ }^{42}$ Electrocautery use during 15 minutes generates plume equivalent to the smoke generated by six nonfiltered cigarettes. ${ }^{39,43}$ The size of particles found in surgical plume varies from $0.05 \mu \mathrm{m}$ to more than $25 \mu \mathrm{m}$ and they can travel up to 1 meter from their source. ${ }^{44,45}$ Particles ranging from $2.5 \mu \mathrm{m}$ to $10 \mu \mathrm{m}$ can enter the respiratory tract and can be found as far distal as the alveoli. ${ }^{44}$ Ultrasmall particles $(0.1-0.8 \mu \mathrm{m})$ had been found in surgical plume from laparoscopic ports after using laparoscopic monopolar cautery. ${ }^{46-50}$ In laparoscopic surgery, the generation of $0.3 \mu \mathrm{m}$ particles was higher after 10 minutes of electrocautery use. ${ }^{42}$

The ultrasonic scalpel produces aerosols without a heating process. This contributes to a higher possibility of carrying viable and infectious particles compared to aerosols from high temperature (electrocautery). Particles generated by ultrasonic scalpel may contain tissue, blood, and its bioproducts. Although currently there is no evidence in the scientific literature, the risk is considered potentially higher in particles generated by the ultrasonic scalpel. More research is needed to determine the potential risk regarding aerosols generated by the ultrasonic scalpel and their ability to spread pathogens and cell components. ${ }^{45}$

\section{Viral Products in Surgical Plume and Transmission Risk}

Human hepatitis virus has been found in surgical plume generated during laparoscopic surgery but its infective capacity as an aerosol has not been determined yet. Nevertheless, it is recommended to establish control methods for the surgical plume generated by electrosurgical devices. ${ }^{51}$

Some studies had identified active human papilloma virus (HPV) and human immunodeficiency virus (HIV) in surgical plume. ${ }^{52-54}$ However, the infectious capacity of these viruses for healthcare workers in the operating room is still not clear. ${ }^{55} \mathrm{~A}$ revision published by the Society of American Gastrointestinal and Endoscopic Surgeons (SAGES) did not find evidence to suggest viral infectivity of electrosurgical instruments including electrocautery and ultrasonic scalpel. ${ }^{39,44}$ In addition, the risk for healthcare workers related to exposition to infective and neoplastic cells found in surgical plume has not been established. ${ }^{56,57}$

Laparoscopic surgery has clinical outcome advantages in patients including those with viral infections such as HIV; it has a lower recovery time, smaller incisions, less respiratory compromise, lower risk of wound dehiscence, lower incisional hernia rate, and lower surgical site infection rate. It also poses less risk of blood and fluid exposition to surgeons. ${ }^{58}$ In general, laparoscopic surgery has the advantage of maintaining the integrity of the abdominal wall, which generates a controlled setting to allow a safe evacuation of pneumoperitoneum and aerosols generated by electrosurgical devices. ${ }^{59-62}$ The use of laparoscopy involves less surgical trauma for the patients compared to open surgery. In the case of a COVID19-positive patient, the minimally invasive approach will likely lead to better survival rates and a faster recovery than the open approach. ${ }^{62,63}$

Until now, the risk of transmission of SARS-CoV-2 or similar viruses such as SARS, MERS-CoV, or influenza, during laparoscopic surgery with the use of electrosurgical devices or robotic surgery, remains unclear. However, considering that SARS-CoV-2 a highly contagious virus is recommended and all precautions should be 
Table 1: Surgical case types classification by indication and urgency

\begin{tabular}{|c|c|c|}
\hline Indication & Time for surgery & Examples \\
\hline Emergent & $\begin{array}{l}\text { Vital emergencies. } \\
\text { Time for surgery } \\
<1 \text { hour }\end{array}$ & $\begin{array}{l}\text { - Life-threating } \\
\text { emergencies } \\
\text { - Acute exsanguination/ } \\
\text { hemorrhagic shock } \\
\text { - Trauma level } 1 \\
\text { activations } \\
\text { - Acute vascular injury or } \\
\text { occlusion } \\
\text { - Aortic dissection } \\
\text { - Emergency C-section } \\
\text { - Acute compartment } \\
\text { - syndrome } \\
\text { - Pecrotizing fasciitis } \\
\text { - Beritonitis } \\
\text { Bowel obstruction/ } \\
\text { perforation }\end{array}$ \\
\hline Urgent & $\begin{array}{l}\text { Time for surgery } \\
<24 \text { hours }\end{array}$ & 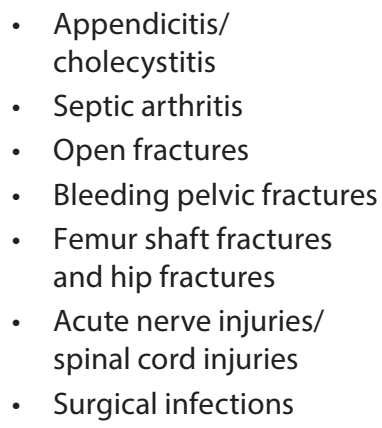 \\
\hline $\begin{array}{l}\text { Urgent- } \\
\text { elective }\end{array}$ & $\begin{array}{l}\text { Low risk to life of } \\
\text { the patient in the } \\
\text { short-term. Time for } \\
\text { surgery }<2 \text { weeks }\end{array}$ & $\begin{array}{l}\text { - Cardiothoracic/ } \\
\text { cardiovascular } \\
\text { procedures } \\
\text { - Cerebral aneurysm } \\
\text { repair } \\
\text { - Vascular access devices } \\
\text { - Skin grafts/flaps/wound } \\
\text { closures } \\
\text { - Scheduled C-section } \\
\text { - Closed fractures } \\
\text { - Spinal fractures and } \\
\text { acetabular fractures }\end{array}$ \\
\hline $\begin{array}{l}\text { Elective } \\
\text { (essential) }\end{array}$ & $\begin{array}{l}\text { Time for surgery } \\
1-3 \text { months }\end{array}$ & $\begin{array}{l}\text { - Cancer surgery and } \\
\text { biopsies } \\
\text { - Subacute cardiac valve } \\
\text { procedures } \\
\text { - Hernia repair } \\
\text { - Hysterectomy } \\
\text { - Reconstructive surgery }\end{array}$ \\
\hline $\begin{array}{l}\text { Elective } \\
\text { (discretionary) }\end{array}$ & $\begin{array}{l}\text { Time for surgery } \\
>3 \text { months }\end{array}$ & 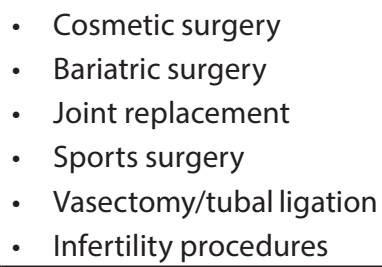 \\
\hline
\end{tabular}

With authorization for: Stahel, Patient Safety in Surgery (2020) 14:8, https://doi.org/10.1186/s13037-020-00235-9 taken to reduce the potential transmission by aerolization in the operating room. ${ }^{39,62-64}$ Every patient with suspected COVID-19 who requires surgery should be treated as COVID-19-positive until proven otherwise. $^{32,63}$ The potential risk of contamination for the surgeon in laparoscopic surgery arises during smoke evacuation by trocars, surgical specimen extraction, or when unnoticed escape of smoke exists toward trocars or incisions. ${ }^{65}$

It is expected that as days go by, the surgical procedures in patients with COVID-19 will substantially increase. Therefore, the implementation of effective mechanisms for surgical plume evacuation and the prevention of aerosol dissemination are required. The use of a simple and low-cost filtration system like electrostatic filters, which have the capability of efficiently filtering bacterial and viral loads, is recommended. ${ }^{66-69}$

The use of appropriate filters for surgical plume evacuation has been recommended by the Centers for Disease Control and Prevention (CDC) even before the pandemic. ${ }^{39,70}$ Filters for surgical smoke evacuation can reduce its inhalation by healthcare workers by about $66 \%{ }^{42}$ These evacuation systems were designed as ultralow particulate air (ULPA) filters that can include activated carbon in their composition to neutralize toxic gases and odor. ${ }^{39,71-73}$

Negative pressure ventilation in the operating room provides an effective way to eliminate contaminant agents for healthcare workers. The use of a hybrid system with unidirectional upward airflow ventilation (UDV) equipped with a high-efficiency particulate air (HEPA) H14 filter in the ceiling of the operating theater with a large airflow volume and well-defined airflow pattern evacuates the surgical smoke nearby the critical area faster and more efficiently than downward displacement airflow systems.

Further, the position of the extraction grilles should be welldefined and localized in order to achieve the best evacuation effect without interfering with obstacles within the critical area. The purpose of the evacuation system is to provide surgical staff with adequate ventilation for contaminant removal, and therefore, decreased levels of personnel exposure to surgical smoke. ${ }^{74}$

We are facing a situation in which we are exposed to a highly contagious virus and new information about the virus is constantly evolving given the short period of time of the pandemic. For this reason, we should do our best effort to minimize the risk of infection with the appropriate use of protective techniques.

There is not clear evidence that laparoscopic surgery poses a high risk for the healthcare workers in the operating room. However as we do not know what the real risk of transmission and infectivity is by being exposed to surgical smoke or pneumoperitoneum evacuation, we recommend avoiding venting surgical plume and pneumoperitoneum directly to the operating room environment. It is essential to use gas evacuation devices and in cases where they are not available, develop a low-cost filtration and suction strategy (Fig. 1).

\section{Recommendations $\mathbf{s}^{32,33,59,60,62,63,75-83}$}

General

- Every patient should be considered COVID-19 positive.

- Indications for emergency surgery and urgent oncological procedures during COVID-19 pandemic should be similar as surgical indications used before the pandemic.

- The operating room should have a negative pressure system.

- The COVID-19 status of the patient should be added to the safety surgery checklist available in the institution. 


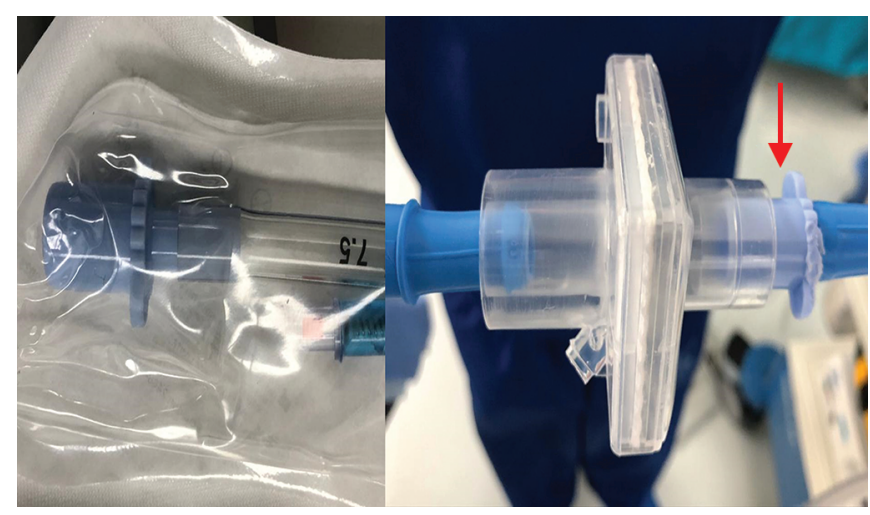

Fig. 1: Adaptation of a filter to the suction system. Red arrow shows clipped adapter to prevent system leakage

- In patients with confirmed or suspected COVID-19 diagnosis, the use of a disposable surgical equipment is recommended to avoid the contamination risk during cleaning and sterilization processes.

- At the institution, an exclusive operative room should be assigned for the procedures in patients with confirmed or suspected COVID-19 diagnosis.

- Keep the doors of the operating room closed during surgery.

- Patients with suspected or confirmed COVID-19 diagnosis require closer surveillance during the postoperative period considering that they are at higher risk of developing a condition requiring ICU management and they also have a higher mortality rate compared with surgical patients without COVID-19.

\section{Healthcare Workers}

- Management guidelines regarding COVID-19 patients undergoing surgery should be individualized according to the reality of the country and the specific healthcare institution.

- The route for transport of COVID-19 patients between the areas of the hospital should be standardized, known by healthcare workers and respected in every case.

- Healthcare workers should receive training in donning and doffing the personal protective equipment.

- Surgical team should wear the personal protective equipment according to CDC guidelines.

- The number of healthcare workers (including surgeons, anesthesiologists, nurses, and technicians) should be limited to the minimum required to safely perform the procedure.

\section{During Laparoscopic Surgery}

- The number and diameter of trocars should be the minimum required to safely perform the procedure.

- The intra-abdominal pressure during laparoscopic surgery should be between 8 and $12 \mathrm{~mm} \mathrm{Hg}$

- Minimize the use of electrosurgical devices, especially ultrasonic scalpel. In case of using monopolar, the energy should be used at the lower intensity to achieve desired effects.

- Surgical plume and pneumoperitoneum should be evacuated in a controlled manner and it is recommended to use an appropriate filter to guarantee safety of healthcare workers.
- Port incisions should be as small as possible to avoid pneumoperitoneum leaks.

- Surgical specimen should be extracted only after the evacuation of pneumoperitoneum

- Drains should be used only if it is strictly needed.

- Fascial closure should start only after active evacuation of pneumoperitoneum.

- Hand-assisted surgery should be avoided.

- Transanal total mesorectal excision (TaTME), transanal minimally invasive surgery (TAMIS), and total mesorectal excision (TME) should be delayed because of the high amount of aerosols generated by these procedures.

\section{References}

1. Givi B, Schiff BA, Chinn SB, et al. Safety recommendations for evaluation and surgery of the head and neck during the COVID-19 pandemic. JAMA Otolaryngol Neck Surg [Internet] 2020(6). DOI: 10.1001/jamaoto.2020.0780Disponible en: https://jamanetwork.com/ journals/jamaotolaryngology/fullarticle/2764032.

2. Leung WK, To KF, Chan PK, et al. Enteric involvement of severe acute respiratory syndrome-associated coronavirus infection. Gastroenterology 2003;125(4):1011-1017. DOI: 10.1016/s00165085(03)01215-0.

3. Gu J, Han B, Wang J. COVID-19: gastrointestinal manifestations and potential Fecal-oral transmission. Gastroenterology 2020;158(6): 1518-1519. DOI: 10.1053/j.gastro.2020.02.054.

4. Zhu N, Zhang D, Wang W, et al. A novel coronavirus from patients with pneumonia in China, 2019. N Engl J Med 2020;382(8):727-733. DOI: 10.1056/NEJMoa2001017.

5. Wölfel R, Corman VM, Guggemos W, et al. Virological assessment of hospitalized patients with COVID-2019. Nature [Internet] 2020(7809). DOI: 10.1038/s41586-020-2196-xDisponible en: http://www.nature. com/articles/s41586-020-2196-x.

6. Chen $\mathrm{H}$, Guo J, Wang C, et al. Clinical characteristics and intrauterine vertical transmission potential of COVID-19 infection in nine pregnant women: a retrospective review of medical records. The Lancet 2020;395(10226):809-815. DOI: 10.1016/S0140-6736(20)30360-3.

7. Chen $\mathrm{Y}$, Peng $\mathrm{H}$, Wang $\mathrm{L}$, et al. Infants born to mothers with a new coronavirus (COVID-19). Front Pediatr 2020;8:104. DOI: 10.3389/ fped.2020.00104.

8. Taylor G, Shannon-Lowe C, Long H, et al. Potential for COVID19 coronavirus (SARS-CoV-2) exposure during laparoscopic gynaecological surgery [internet]. Med Pharmacol 2020. Disponible en: https://www.preprints.org/manuscript/202003.0451/v2.

9. van Doremalen N, Bushmaker T, Morris DH, et al. Aerosol and surface stability of SARS-CoV-2 as compared with SARS-CoV-1. N Engl J Med 2020;382(16):1564-1567. DOI: 10.1056/NEJMc2004973.

10. Crossley J, Clark C, Brody F, et al. Surgical considerations for an awake tracheotomy during the COVID-19 pandemic. J Laparoendosc Adv Surg Tech 2020;30(5):477-480. DOI: 10.1089/lap.2020.0239.

11. COVID-19 situation reports [Internet]. [citado 06 de junio de 2020]. Disponible en: https://www.who.int/emergencies/diseases/novelcoronavirus-2019/situation-reports.

12. Tran K, Cimon K, Severn M, et al. Aerosol generating procedures and risk of transmission of acute respiratory infections to healthcare workers: a systematic review. Semple MG, ed. PLoS ONE 2012;7(4):e35797. DOI: 10.1371/journal.pone.0035797.

13. Chan JF-W, Yuan S, Kok K-H, et al. A familial cluster of pneumonia associated with the 2019 novel coronavirus indicating personto-person transmission: a study of a family cluster. The Lancet 2020;395(10223):514-523. DOI: 10.1016/S0140-6736(20)30154-9.

14. Xia J, Tong J, Liu M, et al. Evaluation of coronavirus in tears and conjunctival secretions of patients with SARS-CoV-2 infection. J Med Virol 2020;92(6):589-594. DOI: 10.1002/jmv.25725. 
15. Holshue ML, DeBolt C, Lindquist S, et al. First case of 2019 novel coronavirus in the United States. N Engl J Med 2020;382(10):929-936. DOI: 10.1056/NEJMoa2001191.

16. Li Q, Guan X, Wu P, et al. Early transmission dynamics in Wuhan, China, of novel coronavirus-infected pneumonia. N Engl J Med 2020;382(13):1199-1207. DOI: 10.1056/NEJMoa2001316.

17. Zhao S, Lin Q, Ran J, et al. Preliminary estimation of the basic reproduction number of novel coronavirus (2019-nCoV) in China, from 2019 to 2020: a data-driven analysis in the early phase of the outbreak. Int J Infect Dis 2020;92:214-217. DOI: 10.1016/ j.ijid.2020.01.050.

18. Bai Y, Yao L, Wei T, et al. Presumed asymptomatic carrier transmission of COVID-19. JAMA 2020;323(14):1406. DOI: 10.1001/jama.2020.2565.

19. Wang D, Hu B, Hu C, et al. Clinical characteristics of 138 hospitalized patients with 2019 novel coronavirus-infected pneumonia in Wuhan, china. JAMA 2020;323(11):1061. DOI: 10.1001/jama.2020.1585.

20. Zhou Z, Zhao N, Shu Y, et al. Effect of gastrointestinal symptoms on patients infected with coronavirus disease 2019. Gastroenterology 2020. S0016508520303620.

21. Song Y, Liu P, Shi XL, et al. SARS-CoV-2 induced diarrhoea as onset symptom in patient with COVID-19. Gut 2020;69(6):1143-1144. DOI: 10.1136/gutjnl-2020-320891.

22. Al-Balas $\mathrm{M}, \mathrm{Al}-\mathrm{Balas} \mathrm{HI}, \mathrm{Al}-\mathrm{Balas} \mathrm{H}$. Surgery during the COVID19 pandemic: a comprehensive overview and perioperative care. Am J Surg 2020(6):S0002961020302221. DOI: 10.1016/j. amjsurg.2020.04.018.

23. Greenland JR, Michelow MD, Wang L, et al. COVID-19 infection: implications for perioperative and critical care physicians. Anesthesiology junio de 2020;132(6):1346-1361. DOI: 10.1097/ ALN.0000000000003303.

24. Zhang L, Zhu F, Xie L, et al. Clinical characteristics of COVID-19infected cancer patients: a retrospective case study in three hospitals within Wuhan. China Ann Oncol 2020(7):S0923753420363833. DOI: 10.1016/j.annonc.2020.03.296.

25. Coronavirus disease 2019 (COVID-19) - symptoms, diagnosis and treatment. BMJ Best Practice [Internet] 2020. Disponible en: https:// bestpractice.bmj.com/topics/en-gb/3000168.

26. Advice on the use of point-of-care immunodiagnostic tests for COVID-19 [Internet]. [citado 16 de mayo de 2020]. Disponible en: https://www.who.int/news-room/commentaries/detail/advice-onthe-use-of-point-of-care-immunodiagnostic-tests-for-covid-19.

27. Miguel IJA, Sociedad Española de Enfermedades Infecciosas y Microbiología Clínica [Internet]. SEIMC. [citado 16 de mayo de 2020]. Disponible en: https://seimc.org/.

28. if-ppih-covid-19-sag-priority-groups-for-asymptomatic-testingrapid-review.pdf [Internet]. [citado 16 de mayo de 2020]. Disponible en: https://www.albertahealthservices.ca/assets/info/ppih/if-ppihcovid-19-sag-priority-groups-for-asymptomatic-testing-rapidreview.pdf.

29. Tao KX, Zhang BX, Zhang P, et al. Recommendations for general surgery clinical practice in novel coronavirus pneumonia situation. Zhonghua Wai Ke Za Zhi 2020;58(0):E001. DOI: 10.3760/cma.j.i ssn.0529-5815.2020.0001.

30. Makison Booth C, Clayton M, Crook B, et al. Effectiveness of surgical masks against influenza bioaerosols. J Hosp Infect 2013;84(1):22-26. DOI: 10.1016/j.jhin.2013.02.007.

31. Benson SM, Novak DA, Ogg MJ. Proper use of surgical N95 respirators and surgical masks in the OR. AORN J 2013;97(4):457-470. DOI: 10.1016/j.aorn.2013.01.015

32. Coccolini F, Perrone G, Chiarugi M, et al. Surgery in COVID-19 patients: operational directives. World J Emerg Surg 2020;15(1):25. DOI: 10.1186/ s13017-020-00307-2.

33. Forrester JD, Nassar AK, Maggio PM, et al. Precautions for operating room team members during the COVID-19 pandemic. J Am Coll Surg 2020(6):S1072751520303033. DOI: 10.1016/j.jamcollsurg.2020.03.030.

34. Birmingham, Intercollegiate Guidance for Pre-Operative Chest CT imaging for elective cancer surgery during the COVID-19 Pandemic
[Internet]. The Royal College of Surgeons of Edinburgh. [citado 16 de mayo de 2020]. Disponible en: https://www.rcsed.ac.uk/ news-public-affairs/news/2020/april/intercollegiate-guidance-forpre-operative-chest-ct-imaging-for-elective-cancer-surgery-duringthe-covid-19-pandemic

35. Stahel PF. How to risk-stratify elective surgery during the COVID-19 pandemic? Patient Saf Surg 2020;14(1):8. DOI: 10.1186/s13037-02000235-9.

36. Lei S, Jiang F, Su W, et al. Clinical characteristics and outcomes of patients undergoing surgeries during the incubation period of COVID-19 infection. E Clin Med 2020;21:100331. DOI: 10.1016/ j.eclinm.2020.100363.

37. Control of smoke from laser/electric surgical procedures. Appl Occup Environ Hyg 1999;14(2):71-71. DOI: 10.1080/104732299303205.

38. Fencl JL. Guideline implementation: surgical smoke safety. AORN J 2017;105(5):488-497. DOI: 10.1016/j.aorn.2017.03.006.

39. Bree K, Barnhill S, Rundell W. The dangers of electrosurgical smoke to operating room personnel: a review. Workplace Health Saf 2017;65(11):517-526. DOI: 10.1177/2165079917691063.

40. Liu Y, Song Y, Hu X, et al. Awareness of surgical smoke hazards and enhancement of surgical smoke prevention among the gynecologists. J Cancer 2019;10(12):2788-2799. DOI: 10.7150/ jca.31464.

41. Ball K. Surgical smoke evacuation guidelines: are you compliant? Nurse 2011;5(6):40-44. DOI: 10.1097/01.ORN.0000398900.12829.09.

42. Li C-I, Pai J-Y, Chen C-H. Characterization of smoke generated during the use of surgical knife in laparotomy surgeries. J Air Waste Manag Assoc 2020;70(3):324-332. DOI: 10.1080/10962247.2020.1717675.

43. Tomita Y,Mihashi S, Nagata K, et al. Mutagenicity of smoke condensates induced by $\mathrm{CO} 2$-laser irradiation and electrocauterization. Mutat Res 1981;89(2):145-149. DOI: 10.1016/0165-1218(81)90120-8.

44. Mowbray N, Ansell J, Warren N, et al. Is surgical smoke harmful to theater staff? a systematic review. Surg Endosc 2013;27(9):3100-3107. DOI: $10.1007 / \mathrm{s} 00464-013-2940-5$.

45. Alp E, Bijl D, Bleichrodt RP, et al. Surgical smoke and infection control. J Hosp Infect 2006;62(1):1-5. DOI: 10.1016/j.jhin.2005.01.014.

46. Andréasson $\mathrm{SN}$, Anundi $\mathrm{H}$, Sahlberg B, et al. Peritonectomy with high voltage electrocautery generates higher levels of ultrafine smoke particles. Eur J Surg Oncol EJSO 2009;35(7):780-784. DOI: 10.1016/ j.ejso.2008.09.002.

47. Brüske-Hohlfeld I, Preissler G, Jauch K-W, et al. Surgical smoke and ultrafine particles. J Occup Med Toxicol 2008;3(1):31. DOI: 10.1186/1745-6673-3-31

48. DesCôteaux J-G, Picard P, Poulin ÉC, et al. Preliminary study of electrocautery smoke particles produced in vitro and during laparoscopic procedures. Surg Endosc 1996;10(2):152-158. DOI: 10.1007/BF00188362.

49. Nezhat C, Winer WK, Nezhat F, et al. Smoke from laser surgery: is there a health hazard? Lasers Surg Med 1987;7(4):376-382. DOI: 10.1002/ Ism.1900070414.

50. Smith J, Yeh HC, Muggenburg B, et al. Study design for the characterization of aerosols during surgical procedures. Scand J Work Environ Health 1992;18(Suppl 2):106-109.

51. Kwak HD, Kim S-H, Seo YS, et al. Detecting hepatitis B virus in surgical smoke emitted during laparoscopic surgery. Occup Environ Med 2016(12):oemed-2016-103724. DOI: 10.1136/oemed-2016103724.

52. Capizzi PJ, Clay RP, Battey MJ. Microbiologic activity in laser resurfacing plume and debris. Lasers Surg Med 1998;23(3):172-174. DOI: 10.1002/(sici)1096-9101(1998)23:33.0.co;2-m.

53. Johnson GK, Robinson WS. Human immunodeficiency virus-1 (HIV-1) in the vapors of surgical power instruments. J Med Virol 1991;33(1):47-50. DOI: 10.1002/jmv.1890330110.

54. Manson LT, Damrose EJ. Does exposure to laser plume place the surgeon at high risk for acquiring clinical human papillomavirus infection?: HPV infection from surgical smoke. Laryngoscope 2013;123(6):1319-1320. DOI: 10.1002/lary.23642. 
55. Neumann K, Cavalar M, Rody A, et al. Is surgical plume developing during routine LEEPs contaminated with high-risk HPV? A pilot series of experiments. Arch Gynecol Obstet 2018;297(2):421-424. DOI: 10.1007/s00404-017-4615-2.

56. Ulmer BC. The hazards of surgical smoke. AORN J 2008;87(4):721-738. DOI: 10.1016/j.aorn.2007.10.012.

57. Lewin JM, Brauer JA, Ostad A. Surgical smoke and the dermatologist. J Am Acad Dermatol 2011;65(3):636-641. DOI: 10.1016/j.jaad.2010. 11.017.

58. Diettrich NA, Kaplan G. Laparoscopic surgery for HIV-infected patients: minimizing dangers for all concerned. J Laparoendosc Surg 1991;1(5):295-298. DOI: 10.1089/Ips.1991.1.295.

59. Di Saverio S, Khan M, Pata F, et al. Laparoscopy at all costs? not now during COVID-19 and not for acute care surgery and emergency colorectal surgery: a practical algorithm from a hub tertiary teaching hospital in Northern Lombardy, Italy. J Trauma Acute Care Surg 2020(6):1. DOI: 10.1097/TA.0000000000002727.

60. JMose B, JMose B, Rubio Pérez I, et al. Manejo quirúrgico de pacientes con infección por COVID-19. Recomendaciones de la Asociación Española de Cirujanos. Cir Esp 2020;98(5):251-259.

61. Singhal R. Internal hernia in the times of COVID-19: to laparoscope or not to laparoscope? Obes Surg [Internet] 2020. Disponible en: http:// link.springer.com/10.1007/s11695-020-04598-x.

62. Vigneswaran Y, Prachand VN, Posner MC, et al. What is the appropriate use of laparoscopy over open procedures in the current COVID-19 climate? J Gastrointest Surg [Internet] 2020. DOI: 10.1007/s11605-02004592-9Disponible en: http://link.springer.com/10.1007/s11605-02004592-9.

63. Morris SN, Fader AN, Milad MP, et al. Understanding the "Scope" of the problem: why laparoscopy is considered safe during the COVID19 pandemic. J Minim Invasive Gynecol 2020;27(4):789-791. DOI: 10.1016/j.jmig.2020.04.002.

64. Brown J. Surgical decision making in the era of COVID-19: a new set of rules. J Minim Invasive Gynecol 2020;27(4):785-786. DOI: 10.1016/ j.jmig.2020.04.001.

65. Chew M, Koh F, Ng K. A call to arms: a perspective of safe general surgery in Singapore during the COVID-19 pandemic. Singapore Med J [Internet] 2020. DOI: 10.11622/smedj.2020049Disponible en: http:// www.smj.org.sg/sites/default/files/CO-2020-115-epub.pdf.

66. Spruce L, Braswell ML. Implementing AORN recommended practices for electrosurgery. AORN J 2012;95(3):373-387. DOI: 10.1016/ j.aorn.2011.12.018.

67. Dellamonica J, Boisseau N, Goubaux B, et al. Comparison of manufacturers' specifications for 44 types of heat and moisture exchanging filters. Br J Anaesth 2004;93(4):532-539. DOI: 10.1093/ bja/aeh239.

68. Mintz Y, Arezzo A, Boni L, et al. A low cost, safe and effective method for smoke evacuation in laparoscopic surgery for suspected coronavirus patients. Ann Surg 2020(1):1. DOI: 10.1097/SLA.0000000000003965.
69. Hanbali N, Herrod P, Patterson J. A safe method to evacuate pneumoperitoneum during laparoscopic surgery in suspected COVID-19 patients. Ann R Coll Surg Engl 2020;102(5):392-393. DOI: 10.1308/rcsann.2020.0079.

70. CDC-NIOSH Study Finds Healthcare Workers' Exposure to Surgical Smoke Still Common - NIOSH Press Release [Internet]. 2019 [citado 16 de mayo de 2020]. Disponible en: https://www.cdc.gov/niosh/ updates/upd-11-03-15.html.

71. Schultz L. An analysis of surgical smoke plume components, capture, and evacuation. AORN J 2014;99(2):289-298. DOI: 10.1016/ j.aorn.2013.07.020.

72. Dobbie MK, Fezza M, Kent M, et al. Operation clean air: implementing a surgical smoke evacuation program. AORN J 2017;106(6):502-512. DOI: 10.1016/j.aorn.2017.09.011.

73. Nishioka Y, Tzeng C-WD, Tran Cao HS, et al. COVID-19 outbreak and surgeons' response at a cancer center in the United States. Glob Health Med 2020;2(2):135-137. DOI: 10.35772/ghm.2020.01021.

74. Romano F, Gustén J, De Antonellis S, et al. Electrosurgical smoke: ultrafine particle measurements and work environment quality in different operating theatres. Int J Environ Res Public Health 2017;14(2):137. DOI: 10.3390/ijerph14020137.

75. Huang C, Wang Y, Li X, et al. Clinical features of patients infected with 2019 novel coronavirus in Wuhan, China. The Lancet 2020;395(10223):497-506. DOI: 10.1016/S0140-6736(20)30183-5.

76. Zou L, Ruan F, Huang M, et al. SARS-CoV-2 viral load in upper respiratory specimens of infected patients. N Engl J Med 2020;382(12):1177-1179. DOI: 10.1056/NEJMc2001737.

77. Caputo KM, Byrick R, Chapman MG, et al. Intubation of SARS patients: Infection and perspectives of healthcare workers. Can J Anesth Can Anesth 2006;53(2):122-129. DOI: 10.1007/BF03021815.

78. Cohen SL, Liu G, Abrao M, et al. Perspectives on surgery in the time of COVID-19: Safety first. J Minim Invasive Gynecol 2020;27(4):792-793. DOI: 10.1016/j.jmig.2020.04.003.

79. Brindle M, Gawande A. Managing COVID-19 in surgical systems. Ann Surg 2020(1):1. DOI: 10.1097/SLA.0000000000003923.

80. Zheng MH, Boni L, Fingerhut A. Minimally invasive surgery and the novel coronavirus outbreak: Lessons learned in china and Italy. Ann Surg 2020(1):1. DOI: 10.1097/SLA.0000000000003924.

81. Novara G, Giannarini G, De Nunzio C, et al. Risk of SARS-CoV-2 diffusion when performing minimally invasive surgery during the COVID19 pandemic. Eur Urol 2020. S0302283820302475. DOI: 10.1016/ j.eururo.2020.04.015.

82. Gao Y, Xi H, Chen L. Emergency surgery in suspected COVID-19 patients with acute abdomen: case series and perspectives. Ann Surg 2020. 1.

83. Tuech J-J, Gangloff A, Di Fiore F, et al. Strategy for the practice of digestive and oncological surgery during the COVID-19 epidemic. J Visc Surg 2020. S1878788620300709. DOI: 10.1016/ j.jviscsurg.2020.03.008. 